J. Reddy Kambam MD, John Hammon MD, Winston C.V. Parris MD, F. Mark Lupinetti MD

\title{
Intrapleural analgesia for postthoracotomy pain and blood levels of bupivacaine following intrapleural injection
}

An epidural type catheter was placed in the pleural space under direct vision before the closure of the chest in 24 patients who underwent thoracotomy for various types of lung or aortic surgery. All patients received intrapleural injections of $20 \mathrm{ml}$ of 0.5 per cent bupivacaine with or without epinephrine as initial pain therapy. Patients also received subsequent doses of a similar volume of 0.375 per cent bupivacaine with epinephrine 1:200,000 up to four times a day for a maximum duration of seven days. Good pain relief was achieved in patients who underwent lateral and posterior thoracotomies. No pain relief was achieved in patients who underwent anterior thoracotomy or in patients in whom there was excessive bleeding in the pleural space. Bupivacaine blood concentrations were measured in // patients following the initial dose of $20 \mathrm{ml}$ of $0.5 \mathrm{per}$ cent bupivacaine (with epinephrine 1:200,000 in five of the II patients). The mean peak plasma concentration of bupivacaine when used with epinephrine was $0.32 \pm 0.02 \mu \mathrm{g} \cdot \mathrm{ml}^{-1}$. The mean peak plasma concentrations of bupivacaine when used without epinephrine was $1.28 \pm 0.48 \mu \mathrm{g} \cdot \mathrm{ml}^{-1}$. Our present data show that intrapleural analgesia is useful in the manage. ment of postoperative pain in patients who undergo thoracotomy. Our data also show that there is a significant decrease in peak plasma concentrations of bupivacaine when epinephrine is added to the solution $(P<0.05)$.

\section{Key words}

ANAESTHESIA: thoraciC; ANAESTHETIC TECHNIQUE: regional intrapleural; sURGERY: thoracotomy; ANAESTHETICS, LOCAL: bupivacaine.

From the Departments of Anesthesiology and Cardiac and Thoracic Surgery, Vanderbilt University Medical Center, Nashville, Tennessee.

Presented at International Anesthesia Research Society 61 st Congress, Lake Buena Vista, Florida, 1987.

Supported by the Study Center for Anesthesia Toxicology, Department of Anesthesiology, Vanderbilt University School of Medicine.

Address correspondence to: Dr. Kambam, Department of Anesthesiology, Vanderbilt University Hospital, Nashville, Tennessee 37232 .
Reiestad et al. recently reported intrapleural analgesia as a new technique for the treatment of postoperative pain in patients who underwent cholecystectomy, renal surgery, and breast surgery. 'The intrapleural technique has several advantages when compared with alternative techniques including intercostal nerve blocks in the treatment of postoperative pain. ${ }^{2-9}$ The purpose of the present study was to investigate the effect of intrapleural administration of bupivacaine in the management of postoperative pain in patients undergoing thoracotomy and to measure the plasma concentrations of bupivacaine following the intrapleural administration of $20 \mathrm{ml}$ of 0.5 per cent bupivacaine with or without epinephrine.

\section{Methods}

Twenty-four patients (both sexes, aged 28-70) who underwent thoracotomy for various types of lung surgery including lobectomy (17 patients), lung biopsy (five patients), and repair of injured thoracic aorta (two patients) were included in this study. Plasma concentrations of bupivacaine were measured in 11 of the 24 patients following intrapleural administration. Following approval from our Institutional Review Board, informed consent was obtained from each of the patients. At the end of the surgical procedure and before the closure of the thorax, an epidural type catheter with a luer-lock rubber cap was placed in the pleural space by the surgeon under direct vision. The catheter was introduced through the intercostal space adjacent to the incision site. The tip of the catheter was placed posteriorly in the pleural space and the catheter was secured with one or two skin sutures. All the patients received $20 \mathrm{ml}$ of 0.5 per cent bupivacaine (15 patients with and nine patients without epinephrine) in the recovery room as initial pain therapy. Subsequent doses of $15-20 \mathrm{ml}$ of 0.375 per cent bupivacaine $\left(0.3 \mathrm{ml} \cdot \mathrm{kg}^{-1}\right.$ to a maximum of $\left.20 \mathrm{ml}\right)$ were given up to four times a day for a maximum duration of seven days. The chest tube was clamped for 5 min following each administration of bupivacaine. The patients were kept in a supine position during and for 10 to 15 minutes following 
the injection. Blood samples were collected through an arterial catheter in 11 patients at the end of $5 \mathrm{~min}, 15 \mathrm{~min}$, $30 \mathrm{~min}, 1 \mathrm{hr}, 2 \mathrm{hr}, 3 \mathrm{hr}$, and $5 \mathrm{hr}$ following the intrapleural administration of the initial dose of $20 \mathrm{ml}$ of 0.5 per cent bupivacaine with epinephrine to five patients (Group 1), and to six patients without epinephrine (Group 2). Plasma was separated immediately and refrigerated for the determination of bupivacaine concentrations by gas chromatography as described by Park et al. ${ }^{10}$

Pain scores were determined using a scale of 0 (complete pain relief) to 10 (unbearable pain). The duration of analgesia was determined from the onset of pain relief until the patient requested a further dose of pain medication. The quality of pain relief was determined both by a physician observer, one of the authors, who administered the anaesthetic and by the patient who received the anaesthetic.

The data were initially assessed for normality using the Shapiro-Wilks test. On the basis of these results, it was decided to use non-parametric tests to compare data for the two groups. The Wilcoxon Rank Sum test was used to test for equality of means. A P value of $<0.05$ was considered significant.

\section{Results}

The results are summarized in Tables I and II. Good pain relief was achieved following intrapleural administration of bupivacaine in patients who underwent lateral and posterior thoracotomies ( $P$ ain Scale $=0$ ). No relief was achieved in three patients who underwent anterior thoracotomies (Pain Scale $=10$ ). No pain relief was achieved in one patient in whom the catheter tip was left anteriorly (Pain Scale $=10$ ) rather than posteriorly, and in another patient in whom there was more bleeding than usual in the thoracic cavity (Pain Scale $=10$ ). No significant difference $(P>0.05)$ in the duration and/or quality of analgesia was noticed between Group 1 patients (bupivacaine with 1:200,000 epinephrine) and Group 2 patients (bupivacaine plain solution). Pain relief was achieved for $6 \pm 1.0$ hours following the initial dose of 0.5 per cent bupivacaine solution. Subsequent doses of 0.375 per cent bupivacaine administration gave $4 \pm 1.0$ hours of pain relief. The time required to reach peak plasma concentrations of bupivacaine following intrapleural injection was $53 \pm 27$ min for epinephrine containing solution and $10 \pm$ 2 min for non-epinephrine containing solution, respectively $(\mathrm{P}>0.05)$. There is a significant difference $(\mathrm{P}<$ $0.05)$ in the peak plasma concentrations of bupivacaine between epinephrine containing $\left(0.32 \pm 0.02 \mu \mathrm{g} \cdot \mathrm{ml}^{-1}\right)$ and plain $\left(1.28 \pm 0.48 \mu \mathrm{g} \cdot \mathrm{ml}^{-1}\right)$ solutions of bupivacaine.

No complications were noticed even when the catheter was left in place for one week. Two patients complained
TABLE I Efficacy and duration of pain relief following intrapleural analgesia in postthoracotomy patients

\begin{tabular}{lllll}
\hline & & \multicolumn{3}{l}{ Pain Relief* } \\
\cline { 3 - 5 } Patients & $\begin{array}{l}\text { Thoracotomy } \\
\text { type }\end{array}$ & $\begin{array}{l}\text { None } \\
n\end{array}$ & $\begin{array}{l}\text { Good } \\
\text { Anterior }\end{array}$ & $\begin{array}{l}\text { Duration } \\
\text { Hrs }\end{array}$ \\
\hline 3 & Posterior; lateral & 2 & 19 & $6 \pm 1$ \\
\hline 21 & 2 & $n$ & \\
\hline
\end{tabular}

*No significant difference $(\mathrm{P}>0.05)$ between epinephrine $(15$ patients) and non-epinephrine (nine patients) containing bupivacaine.

TABLE Il Plasma bupivacaine concentrations $\left(\mu \mathrm{g} \cdot \mathrm{ml}^{-1}\right.$ ) following intrapleural injection in 11 postthoracotomy patients

\begin{tabular}{|c|c|c|c|c|c|c|c|}
\hline \multirow[b]{2}{*}{ Patients } & \multicolumn{7}{|c|}{ Time after injection (min) } \\
\hline & 5 & 15 & 30 & 60 & 120 & 180 & 300 \\
\hline \multicolumn{8}{|l|}{ Group I* } \\
\hline 1 & 0.1 & 0.2 & 0.2 & 0.2 & 0.3 & 0.1 & 0.0 \\
\hline 2 & 0.3 & $\mathrm{NM}$ & 0.3 & 0.3 & 0.4 & 0.3 & 0.2 \\
\hline 3 & 0.3 & 0.1 & 0.1 & 0.1 & 0.1 & 0.1 & 0.1 \\
\hline 4 & 0.3 & 0.2 & 0.2 & 0.1 & 0.1 & 0.1 & 0.1 \\
\hline 5 & 0.2 & 0.3 & 0.2 & 0.2 & 0.1 & 0.1 & 0.1 \\
\hline Mean & 0.25 & 0.17 & 0.20 & 0.18 & 0.23 & 0.15 & 0.10 \\
\hline SEM & 0.06 & 0.04 & 0.05 & 0.06 & 0.09 & 0.06 & 0.05 \\
\hline \multicolumn{8}{|c|}{ Group Il $\dagger$} \\
\hline 1 & 1.1 & 1.0 & 0.7 & 0.4 & 0.5 & 0.3 & 0.2 \\
\hline 2 & 3.5 & 3.6 & 2.7 & 1.0 & 0.6 & 0.2 & 0.2 \\
\hline 3 & 1.2 & 0.7 & 0.7 & 1.0 & NM & 0.5 & 0.2 \\
\hline 4 & 0.8 & 0.8 & 0.7 & 0.5 & 0.3 & 0.2 & 0.1 \\
\hline 5 & 0.3 & 0.4 & 0.3 & 0.2 & 0.2 & 0.1 & 0.1 \\
\hline 6 & 0.5 & 0.6 & 0.6 & 0.1 & 0.1 & 0.1 & 0.1 \\
\hline Mecan & 1.23 & 1.18 & 0.95 & 0.53 & 0.34 & 0.23 & 0.15 \\
\hline SEM & 0.47 & 0.49 & 0.35 & 0.15 & 0.09 & 0.06 & 0.02 \\
\hline
\end{tabular}

*Patients received bupivacaine with epinephrine, 1:200,000 (Peak bupivacaine level $=0.32 \pm 0.02 \mu \mathrm{g} \cdot \mathrm{ml}^{-1}$ )

$\dagger$ Patients received bupivacaine without epinephrine (Peak bupivacaine level $\left.=1.28 \pm 0.48 \mu \mathrm{g} \cdot \mathrm{ml}^{-1}\right)$. Significant difference $(P<0.05)$ in the peak blood levels of bupivacaine between two groups: $\mathrm{NM}=$ Not measured

of slight tingling and numbness in both upper extremities with the initial dose, suggesting the possibility of epidural spread of local anaesthetic. However, neither sensory level nor cardiovascular changes were seen in these two patients. Both patients had good pain relief.

\section{Discussion}

Incisional pain resulting in hypoventilation and hypoxaemia is one of the immediate postoperative problems encountered by surgeons and anaesthetists in some of the patients who undergo thoracotomy. Parenteral and epidural administration of narcotics, infiltration of incisional site with local anaesthetics, and intercostal nerve blocks 
are some of the techniques used to control postoperative pain. ${ }^{2-9}$

Our present study showed that intrapleural analgesia is useful in treating postoperative pain in patients who undergo lateral and posterior thoracotomies and may not be effective in patients who undergo anterior thoracotomy. The number of patients we studied is too small to comment why this technique is not effective in anterior thoracotomies. Our data also suggest that bupivacaine probably should be used with epinephrine as peak concentrations measured were much less when bupivacaine was used with epinephrine.

Since Reiestad et al. described the intrapleural technique for postoperative pain relief in 1986, several investigators have reported its usefulness in the management of pain following cholecystectomy and other abdominal operations. ${ }^{11-14}$ However, there have been conflicting reports about its usefulness in patients who undergo thoracotomy. ${ }^{15-17}$ Some of the reasons for these conflicting results in posthoracotomy patients include: (1) loss of local anaesthetic via chest tube, (2) dilution of local anaesthetic by the residual irrigation fluid and/or blood, (3) binding of local anaesthetic to the blood proteins in the presence of an haemothorax, and (4) possible rapid absorption of local anaesthetic via the injured lung. Our results are not in agreement with that of Rosenberg et al. ${ }^{16}$ We clamped the chest tube for 5 to 10 mins and left the patients in the supine position to prevent local anaesthetic loss in the chest tube and to facilitate the local anaesthetic to spread more posteriorly in the pleural space. It is important because the intercostal nerve in the paravertebral area is separated from the pleura only by the covering of the endothelial fascia. Rosenberg er al. found a significant amount of local anaesthetic in the contents of chest tube drainage. ${ }^{16}$ This loss of local anaesthetic especially in the first 5 mins may be the reason for their unsatisfactory results.

We believe that the intrapleural technique has many advantages when compared with intercostal nerve blocks in the management of thoracotomy pain. These include: (1) the intrapleural technique is simple, (2) since the catheter is placed in the pleural space under direct vision, the chance of intravascular injection of local anaesthetic is minimal, and (3) the plasma concentrations of local anaesthetic solution are three to four times lower. The plasma concentrations of bupivacaine that can cause convulsions in man have been reported to be as low as $2.3 \mu \mathrm{g} \cdot \mathrm{ml}^{-1}$ and as high as $4.0 \mu \mathrm{g} \cdot \mathrm{ml}^{-1} \cdot{ }^{18-20}$ Intrapleural analgesia should not be used when there is local infection, pleural effusion, broncho-pleural fistula, or in situations where clamping of the chest tube for a few minutes might not be safe.

The mechanism of action of intrapleural analgesia is not known. Reiestad et al. ${ }^{1}$ postulated that local anaesthetic solution probably diffuses into several intercostal nerves to produce pain relief. However, unlike intercostal nerve blocks, intrapleural analgesia does not produce surgical anaesthesia and thus is not useful for surgical procedures.

In conclusion, our results show that intrapleural analgesia is a new and useful technique in the management of postoperative pain in patients who undergo thoracotomy for various types of pulmonary and thoracic vascular surgery. Further controlled comparative clinical studies are necessary before the final role of intrapleural analgesia in postoperative thoracotomy pain management can be assessed.

\section{References}

1 Reiestad F, Stromskag KE. Intrapleural catheter in the management of postoperative pain, a preliminary report. Regional Anesth 1986; 11: 89-91.

2 Griffiths DPG, Diamond AW, Cameron JD. Postoperative extradural analgesia following thoracic surgery: a feasibility study. Br J Anaesth 1975; 47: 48-55.

3 Bromage PR, Camporesi E, Chesinut D. Epidural narcotics for postoperative analgesia. Anesth Analg 1980; 59: 473-80

4 Cousins MJ, Mather $L E$. Intrathecal and epidural administration of opioids. Anesthesiology 1984; 61: 276-310.

5 Kaplan JA, Miller ED, Gallagher EG. Postoperative analgesia for thoracotomy patients. Anesth Analg 1975; 54: $773-7$.

6 Galway $J E$, Caves $P K$, Dundee JW. Effect of intercostal nerve blockade during operation on lung function and relief of pain following thoracotomy. $\mathrm{Br} \mathrm{J}$ Anaesth 1975 ; 47: 730-5.

7 Faust RJ, Nauss LA. Post-thoracotomy intercostal block: comparison of its effects on pulmonary function with those of intramuscular meperidine. Anesth Analg 1976; 55: 542-6.

8 Miller JL, Gertel M, Fox GS, Maclean PD. A comparison of the effect of narcotic and epidural analgesia on postoperative respiratory function. Am J Surg 1976; 13I: 291-4.

9 Wahbo WM, Don $H F$, Craig $D B$. Postoperative epidural analgesia: effect on lung volumes. Can Anaesth Soc J 1975; 22: 519-27.

10 Park GB, Erdmansky PE, et al. Analysis of mepivacaine, bupivacaine, etidocaine, lidocaine and tetracaine. J Pharm Sci 1980; 69: 603-5.

11 Selizer $J L$, Larijani GE, Goldberg ME, Marr AT. Intrapleural bupivacaine - a kinetic and dynamic evaluation. Anesthesiology 1987; 67: 798-800.

12 Brismar B, Petterrson N. Tockics L, Strandberg A, Hedensterna $G$. Post-operative analgesia with intra- 
pleural administration of bupivacaine-adrenalin. Acta Anesthesia Scand 1987; 31: 515-20.

13 Stromskag KE, Reiestad F, Homqvist E, Ogenstad S. Intrapleural administration of $0.25 \%, 0.375 \%$, and $0.5 \%$ bupivacaine with epinephrine after cholecystectomy. Anesth Analg 1988; 67: 430-4.

14 Bruce D, Gerken V, Lyon G. Post-cholecystectomy pain relief by intrapleural bupivacaine in patients with cystic fibrosis. Anesth Aralg 1987; 66: 1187-9.

15 Mcllwaine WB, Knox RF, Fennessey PV, Goldstein $M$. Continuous infusion of bupivacaine via intrapleural catheter for analgesia after thoracotomy in children. Anesthesiology 1988; 69: 261-4.

16 Rosenberg PH, Scheinin B, Lepantalo $M$, Lindfors $O$. Continuous intrapleural infusion of bupivacaine for analgesia after thoracotomy. Anesthesiology 1987; 67: 811-3.

17 Kambam JR, Handte RE, Flanagan J, Fisher K, Lupinetti $M$, Hammon $J$. Intrapleural anesthesia for post thoracotomy pain relief. Anesth Analg 1987; 66: S191.

18 Moore DC, Mather LE, Bridenbaugh PO, et al. Arterial and venous plasma levels of bupivacaine following epidural and intercostal nerve blocks. Anesthesiology 1976; 45: 39-45.

19 Ryan DW. Accidental intravenous injection of bupivacaine: a complication of obstetrical epidural and intercostal nerve blocks. Br J Anaesth 1973; 45: 907-8.

20 Crawford ED, Skinner DG. Intercostal nerve block with thoracoabdominal and flank incisions. Urology 1982 19: $25-8$.
Résumé

Chez 24 patients, lors d'une thoracoromie pour chirurgie aortique ou pulmonaire, nous avons laissé un cathêter de type épidural dans la cavité pleurale. A titre d'analgésique, nous y avons d'abord injecté $20 \mathrm{ml}$ de bupivacaine 0.5 pour cent avec ou sans adrénaline 1:200,000. Nous avons poursuivi la thérapie à raison de doses de $20 \mathrm{ml}$ de bupivacaine 0.375 pour cent avec adrénaline $1: 200,000$ injectées jusqu'à quatre fois par jour durant un maximum d'une semaine. L'analgésie s'est avérée adéquate dans les cas de thoracotomies postérieures ou latérales mais insuffisante pour les thoracotomies antérieures ou en présence d' hémorragie intrapleurale. Après la première dose de $20 \mathrm{ml}$ de bupivacaine 0.5 pour cent, nous en avons mesuré les taux sériques chez_Il patients (dont cinq avaient de l'adrénaline 1:200,000 mélangée à l'anesthésique local). Administrée seule, la bupivacaine atteignait un taux sérique maximal moyen de $1.28 \pm 0.48 \mu \mathrm{g} \cdot \mathrm{ml}^{-1}$ alors que l'adjonction d'adrénaline réduisait cette valeur d $0.32 \pm 0.02 \mu \mathrm{g} \cdot \mathrm{ml}^{-1}$ $(P<0.05)$. En postopératoire d' une thoracotomie, l'analgésie intra-pleurale s'avere utile et l'addition d'adrénaline a la bupivacaïne en réduit le taux sérique maximal. 